\title{
Irregular Antibodies Identified Previously In Blood Transfusions: A Review Of The 21st Century
}

\author{
Patrícia Rodrigues Lima ${ }^{1}$, Afrânio Côgo Destefani ${ }^{1 *}$ \\ ${ }^{1}$ Federal University of Espírito Santo, Brasil \\ *Corresponding Author: Afrânio Côgo Destefani: afraniocd@gmail.com
}

\section{OPEN ACCESS}

Citation: Lima P.R., Destefani A. C. (2016) Irregular Antibodies Identified Previously In Blood Transfusions: A Review Of The 21st Century. Open Science Journal 2(1).

Received: $15^{\text {th }}$ December 2016

Accepted: $14^{\text {th }}$ January 2017

Published: $16^{\text {th }}$ January 2017

Copyright:@ 2016 This is an open access article under the terms of the Creative Commons

Attribution License, which permits unrestricted use, distribution, and reproduction in any medium, provided the original author and source are credited.

Funding: The author(s) received no specific funding for this work

Competing Interests: The author have declared that no competing interests exists.

\section{Abstract:}

Introduction: In the blood transfusion patients may be exposed or are stimulated to produce red cell antibodies that cause immediate and delayed transfusion reactions. Antibodies that agglutinate the red blood cells are called signifiers. Already insignificant antibodies that agglutinate red blood cells "in vitro", and which do not promote changes in the body can be sub-categorized into Rh and Kell system, MNSs, Lewis, Duffy and Kidd.

Objectives: Identify the types of irregular antibodies.

Materials and Methods: This study was conducted through a wide reading-based research papers published from 2000 to 2014 available on the websites: Scielo - Scientific Electronic Library Online, LILLACS - Latin American and Caribbean Sciences WWII Health and PubMed - US National Librany of Medicine and BIREME - Regional Library of Medicine. Inclusion criteria were: articles published in Portuguese, English and Spanish and exclusion criteria: review articles that do not directly addressed the issue of irregular antibodies and blood transfusion.

Results and Discussion: We identified 51 articles on alternate sites: 43 in Scielo, 2 in BIREME, 1 in LILLACS and 5 found in PubMed. Only 22 articles met the inclusion criteria proposed for the study and were distributed in several categories: descriptive, quantitative and qualitative research. 
Conclusion: Common antibodies are $\mathrm{Rh}$ and Kell system. Erythrocyte sensitizations occur to each unit of transfused red blood cells. Therefore, phenotyping and genotyping for Rh, Kell, Duffy, Kidd and MNSs antibodies to patients undergoing blood transfusion is recommended for safe and quality therapy.

Keywords: Antibodies, Significant and insignificant antibodies, Erythrocyte awareness, Autoantibodies, Blood transfusion and alloimmunization.

\section{Introduction}

Patients who require transfusion of red blood cell (RBC) concentrates are exposed or produce irregular antibodies that cause reactions against one or more red blood cells. This is because erythrocyte antigens are structures that are located on the erythrocyte membrane and detected by alloantibodies. The incidence of irregular antibodies is related to RBC transfused without phenotyping, the importance of which is related to the ability of the antigen to induce and react to an immune response when the subject's immune system is compromised due to the advancement of the disease, which reduces the immunological components exposing the patient to erythrocyte sensitization (BORDIN, 2007).

Blood transfusions are known to involve risks which include viral, bacterial, hemolytic antibody reactions, blood incompatibility, mild, moderate, and severe adverse reactions. Patients who undergo blood transfusions in cases of urgency and emergency are often transfused without performing the compatibility test at the written request or by signing the term of responsibility of the requesting physician. In the case of non-chronic and acute diseases, pre-transfusion tests are already performed to determine blood group $\mathrm{A}, \mathrm{B}, \mathrm{O}$ and $\mathrm{Rh} \mathrm{D}$ factor upon medical request. The procedures performed to blood transfusions are the pretransfusion research and research irregular antibodies (RIA) that are performed in blood samples from patients prior to blood transfusions (ANDRADE MVM, et al. 2010).

PAI is also performed in patients with chronic and non-chronic diseases, who have thalassemia, sickle cell anemia, neoplasms and in cases of urgency and emergency. The haemotherapic transfused these diseases should have the same antibodies of patients to prevent immediate reactions, and delayed sensitization by antibodies (ANDRADE ${ }^{\mathrm{a}}$ M.V.M, et al. 2010).

There are several types of irregular antibodies in different forms. After the discovery of blood groups, A, B, O in 1900 by Karl Landsteiner, this one found several antigens and antibodies in the membranes of the erythrocytes. These antibodies were classified as significant when they agglutinated the red blood cells, reducing the survival of red blood cells; And insignificant when they agglutinated the red blood cells, but did not affect survival in the organism. 
These antibodies were named as Rh and Kell system, MNSs, Lewis, Duffy and Kidd; these are identified in serum or plasma from donors and in patients who undergo blood transfusion. This is because each of these antigens have biological functions that are capable of causing red cell reactions when in contact with human antigen causes immediate reactions, late or the sudden death of the patient (CASTILHO I., 2008).

After the knowledge of the antibodies of the Rh and Kell system, MNSs, Lewis, Duffy and Kidd, they were enrolled in hemotherapy programs, thus preventing and mitigating the risk of erythrocytic reactions and sensitization in patients (MEDEIROS et al., 2010).

Due to the importance of $\mathrm{ABO}$ and $\mathrm{Rh}$ factor mapping in blood donors and patients, blood donation of all blood donors and patients for the Rh, Kell, MNSs, Lewis, Duffy and Kidd systems has become mandatory; these patients were enrolled in hemotherapy programs, thus preventing and mitigating the risk of reactions and sensitization (MEDEIROS et al., 2010).

The need for knowledge of the Rh and Kell system is of great clinical importance. The ABO system has the antigens of the Rh and Kell system on its surface membranes, these existing plasma antibodies related to the Rh and Kell systems that bind to the patient's red blood cells causing transfusional hemolytic reactions (PINHEIROS et al., 2013).

All hemotherapy services must follow mandatory norms established by Brazilian Resolution $N^{\circ}$. 153 of the National Sanitary Surveillance Agency (ANVISA), which determines technical procedures for the use of hemotherapy products, which are: collection, processing, testing, storage, transportation, quality control, and he human use of venous blood, umbilical cord, placenta and bone marrow; failure to comply with these rules shall be governed according to the penalties described in Law No .6437 of August 20, 1977 (ANDRADE ${ }^{\text {b M.V.M }}$ et al. 2014).

\section{Erythrocyte polymorphism}

Erythrocyte polymorphism is a feature of great importance for the categorization of individuals regarding the antigens present in the red blood cell membrane and also contributes to the currently seen causes of hemolytic transfusion reactions (HARMENING p. 119; 2006).

Blood group antigens have a genetic characteristic due to the presence of proteins, glycoproteins or glycolipids in the plasma membrane of blood cells. Thus, blood groups are established according to the antibody currently observed on the surface of the erythrocyte membrane. It is important to note that not all polymorphisms are characteristic of a blood group (HARMENING p. 120-121; 2006).

With the discovery of the system of blood groups by Karl Landsteiner, to date this system is of great clinical importance due to the results obtained through experiments performed by the scientist in blood samples, observing agglutinations in some of these samples classifying the blood groups as (A, B and O) (HARMENING p. 119-121; 2006). 
About the existence of approximately 250 different types of erythrocyte antigens, currently the most frequent antibodies of the blood groups are of the ABO system, which has antigens of the system Rh and Kell and the antibodies of the system Kidd, Duffy and MNSs. These antibodies and antigens can be identified in erythrocyte associations reacting together with other antibodies causing changes in the patient's immune response, which stand out as immediate and late reactions occurring in blood transfusions (HARMENING p. 120-121; 2006).

In addition to these antibodies, observed other antibodies that may cause transfusion reactions that are classified as anti-Dia (Diego) and anti-U. Anti-Dia is an unusual but clinically important antibody. It can cause newborn hemolytic disease (NHD) and heterologous transfusion reaction (HTR) (HIRTSCH et al. 2004). Anti- $U$ antibody is an alloantibody that is detected in black individuals and can cause NHD and hemolytic transfusion reactions (CHAMONE et al. 2003).

Erythrocyte antibodies have several biological functions, which may be structural, structural and transport, receptor and adhesion function, enzyme or complement elements.

Through genetic studies correlated to these antigens, protocols were developed that migrated to technical regulation to identify the erythrocyte phenotypes by: genotyping, serological methods, antiglobulin test (AGT), blood compatibility and RIA (VIEIRA et al. 2009). The use of this regulation prevents health problems and increases the risk of erythrocyte sensitization.

In 1964, the Brazilian Ministry of Health established mandatory standards and protocols for the implementation of activities in the hemotherapy service, regulating imports and exports of hemotherapy products, mandatory inclusion of care with blood donors and patients, records in the blood public and private bodies and the carrying out of serological tests (BRITO et al. 2014).

Currently the technique of blood group genotyping for blood transfusions is being used with high-technology and lower-cost equipment for patient care, such as PCR (polymerase chain reaction) and PCR-RFLP (polymerase chain reactionrestriction fragment length polymorphism). These technologies facilitate the identification of antibodies, as well as enable partial or total "donor" screening of blood donors and $\mathrm{Rh}$ negative patients. This technique guarantees the detection of antibodies up to two days after transfusions, preventing future secondary sensitization (VIEIRA et al., 2009).

\section{Significant antibodies}

\section{Rh system}

The antigens of this system have a high complexity to the anti-D antibody which is considered the most immunogenic antibody. The main antigen of this system is $\mathrm{D}$ antigen due to its high degree of immunogenicity. D antigen is encoded by the RHD gene in Rh positive individuals, observed that in the absence of the gene, there will be no production of the respective antigen. Individuals who have it are classified as $\mathrm{Rh}$ positive, while $\mathrm{Rh}$ negative does not contain this antigen. In pre-transfusion searches these antigens may be associated with other antigens of the Rh system which are anti-D / -C and anti-E / -c. The sensitivity of these antigens is due to the fact that red blood cell concentrates 
transfused without erythrocyte phenotypes cause primary or secondary immunological response in the patient (STINGHEN et al., 2011).

COVAS et al., in 2007, mentioned that anti-D antibody visualization is due to maternal or paternal sensitization corresponding to blood incompatibility and also influenced by $\mathrm{Rh}$ factor. In the transfusion routine, $\mathrm{Rh}$ negative individuals who receive a transfusion of $200 \mathrm{~mL}$ of blood containing $\mathrm{D}$ antigen can be sensitized by that antigen. Maternal sensitization to the fetus may be of paternal origin, since the antibody present in the serum of Father Rh- can sensitize the Rh-mother, causing erythrocytic alloimmunization in the fetus during pregnancy (Nardo et al., 2009). This fetal alloimmunization that occurs during pregnancy is due to the fact that mothers with $\mathrm{Rh}$ negative do not present due anti-D immunoprophylaxis and are unaware of the partner's blood type A, B, O, causing future transfusion reactions in cases of hemotherapy (MORON et al., 2010).

Possible extracellular variations of $\mathrm{RhD}$ protein occurring in the $\mathrm{D}$ antigen are induced by mutations of the epitopes causing partial loss of the genetic material which evolves into an anti-D alloantibody or a poor decrease in RhD antigen expression. This genetic mutation generates amino acid substitutions that interfere with the production of membrane and intracellular proteins, more specifically RHD proteins. We have a low expression of the D antigen protein, which makes it possible to categorize individuals with low or total $\mathrm{Rh}$ weak related to D (CASTILHO ${ }^{\text {b }}$ et al., 2006).

\section{Kell system}

The Kell system consists of 20 antigens, the first antigen was K (Kell or K1), soon followed by the $\mathrm{k}$ antigen (Cellano or $\mathrm{k} 2$ ). These antigens are capable of sensitizing one individual to every 10 units of red blood cell concentrates transfused in a negative Kell patient. The antigens of the kell system are expressed in the red blood cell membrane and are also found in lymphatic tissues, skeletal muscles, lymphoid organs and so on. (HARMINGING p. 178, 2006).

When the Kell system antigens are identified in the plasma of a newborn, it can progress to severe hemolytic anemia, as it causes an inhibitory effect on

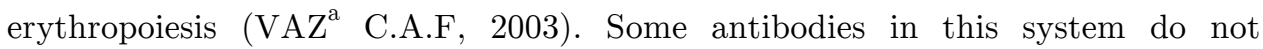
activate the complement (plasma) even though they are IgG, but they can agglutinate Kell positive red cells in human serum. When they react at $37^{\circ} \mathrm{C}$ there is no complement activation (plasma), but they can cause extravascular hemolysis and also cause intravascular intravascular haemolysis in the blood vessels due to a weak reaction. Complementarily, hemolysis occurs in the vascular bed, leading to hepatic impairment leading to an increase in plasma hemoglobin and saturation of the hepatoglobin transport protein (HARMENING p. 179, 2006). When Kell system antigens are present in donor blood and red blood cells are transfused in patients with negative Kell antigen, immediate, late hemolytic reactions and erythrocyte sensitizations occur (BORDIN, 2007).

\section{Duffy system}

Most of the antibodies in this system are identified in association with other antibodies activating the complement (plasma) because they are IgG. They can be classified as anti-Fya which is an antibody identified in complement (plasma) and is also an IgG, causing post-transfusion hemolytic reaction and DHPN rarely occurs. Anti-Fyb is difficult to find alone and is activated together with other 
antibodies causing transfusion reactions (COVAS et al., 2007). These antibodies react on direct and indirect human antiglobulin tests, but may be masked with the use of enzymes (VAZ ${ }^{\mathrm{b}}$ C.A.F., et al. 2001).

In the transfusion practice, Fya and Fyb are considered the main antigens of the system. Fya antigen has a high frequency in Asian individuals, approximately $100 \%$ of the population, has a frequency three times lower than anti-k. However, anti-Fyb is less frequent in the population than anti-Fya and is generally identified in association with other antibodies (COVAS et al., p. 148-149, 2007)

The Duffy system has a biological function acting as a merozoite receptor for Plasmodium vivax, a parasite that causes malaria. In the studies of NOVARETTI et al., 2005 patients with erythrocytes Fy (a- b-) have a resistance in the membranes of the erythrocytes that blocks the invasion of malaria parasites.

\section{Kidd system}

This system is composed of less frequent antibodies classified as anti-Jka and anti-Jkb. Because they are IgG they react together with other antibodies and are identified in complement in the $\operatorname{IgM}$ or $\operatorname{IgG}$ phases in the plasma of the patient who received blood transfusion. The antigens of this system are classified as Jka and $\mathrm{Jkb}$ cause immediate and late hemolytic reactions and in some cases DHPN (COVAS p.156-157; 2007).

Anti-Jka and anti-Jkb antibodies are not found in tissues, usually those antibodies are identified in the pre-transfusion searches associated with other antibodies. Anti-JKA has a higher frequency in individuals than anti-JKb, and can be identified in association with other antibodies in the IgG and IgM phase (COVAS et al., p. 157-158; 2007).

\section{Lewis system}

This system is related to the antibodies identified in the Rh system protein. It represents about $20 \%$ of the irregular antibodies identified in individuals who have the Lea and Leb antibodies; Is often not derived from a history of alloimmunization (COVAS et al., p. 153-154, 2007). It is found only in individuals whose red blood cells are Le (a- b-); Especially in women in the reproduction period. There is still no plausible explanation for this fact (HARMINGING, p. 151-153, 2006).

Most antibodies to the anti-Lewis system are IgM and react at a temperature of $30^{\circ} \mathrm{C}$ and remain activated in the complement. Due to the fact that they react below the temperature of $30^{\circ} \mathrm{C}$, they are considered as natural antibodies (HARMENING p. 152, 2006).

Individuals who have antibodies to the Lewis system do not have alloimmunization information, but already those that have antibodies can raise the titration of existing antibodies, resulting in the production of antibodies in individuals who do not possess the Lewis system. Antigens from the Lewis system are classified as anti-Lea and anti-Leb antibodies that are poorly potent because they are IgM and are rarely IgG, but may cause in vitro hemolysis; These antigens are common in individuals of blood groups A and B (COVAS et al., 143, 2007). 


\section{Insignifying antibodies}

\section{MNSs system}

The antigens of this system are naturally occurring and are considered polyphomorphic because of the antigenic association to glycophorins A and B that are located in the erythrocyte membrane. These glycophorins express autoantibody activities of the MNSs system, but not all the occurrence of these autoantibodies is related to this system. Glycophorin A expresses anti-M or anti$\mathrm{N}$ antigen activities, whereas anti-N and anti-S anti-s antigens are expressed by glycophorin B (HARMENING p.166; 2006).

Antigens from this system are identified by the screening of low and high frequency antibodies in cases of unexpected incompatible cross reaction. They have clinical significance when they react to $\operatorname{IgG}$ or $\operatorname{IgM}$ in the hot or cold phases (HARMENING p.170; 2006).

\section{Human antiglobulin tests}

The human antiglobulin (HAG) test is done by two direct and indirect methods.

\section{Direct method}

It is a widely used method for the detection of autoimmune hemolytic anemias and in hemolytic transfusion reactions and hemolytic diseases of the newborn. The direct method is simple and detects RBC sensitization in vivo in the IgG phase or components it can activate. This technique can be performed in a tube or gel. In the tube method, the serum of human antiglobulin is added to the red cells under test, previously washed with saline. By the gel method, it is not necessary to wash the red cells, only added to the red cells diluted in the HAG-containing gel (NETO et al. 2013). The test identifies IgG-phase sensitized red blood cells or antibodies activated by induction of drugs such as penicillin, methyldopa, quinine, phenacetin and others that may cause reactivity in this test. There are also reports that some illnesses related to infections, immune disorders, cardiolipin, acquired immunodeficiency syndrome, malignant diseases, solid tumors, hematological diseases (macrocytic or microcytic anemias), early stage breast cancer can trigger positivity to the membranes of the red blood cells, Causing hemolytic reactions observed in the human antiglobulin test (PLETSCH et al., 2013).

To understand the positivity of the direct antiglobulin test, it is necessary to know the clinical situation of the patient, such as type of drug therapy, transfusion history, age among others (PLETSCH et al., 2013). For the same purpose there is also the quick direct manual test of low cost TPD Hexadimetrine bromide (Polybreneß) used for the detection of autoimmune hemolytic anemia. It is based on a technique where blood is preserved in test tubes containing sodium citrate, which avoids the aggregation of red cells by IgG (KURODA et al., 1998). 


\section{Indirect method}

It is also used to detect antibodies present in plasma or serum. These antibodies are observed in the tests in red cells with the use of commercial reagents tested in the serum or plasma of the patient or blood donor, observing the sensitization of the receptor with the red blood cells of the donor. The indirect method is known as Coombs Indirect method, detects the presence of antibodies in serum or plasma. The reagent red cells used in this method are marketed cells that are used to identify which cell occurs in the erythrocyte positivity that are referred to as a screening or screening panel (NETO et al., 2013).

The Antiglobulin Test is used to:

- Erythrocyte Phenotyping - Used to detect the antigens present in serum or plasma, identifying for example: anti-D with weak D determination; determine the anti-Kell antigen; and others (NETO et al., 2013).

- Irregular antibody screening - Used to detect antibodies present in serum or plasma and monitor negative Rh (D) in pregnant women (NETO et al. 2013).

- Cross-test - To detect agglutination caused by antibodies present in serum or plasma of the recipient, when tested with donor red blood cells (NETO et al. 2013).

- Identification of irregular antibodies - To detect the types of antibodies after an agglutination observed in the pregnant sample, patients who undergo blood transfusion (NETO et al. 2013).

\section{Materials and methods}

This study was carried out through a bibliographical research based on a broad reading in scientific articles published in the period from 2000 to 2014 available on the following websites: SciELO - Scientific Electronic Library Online, LILLACS - Latin American and Caribbean Literature on Health Sciences, PubMed - US National Librany of Medicine and BIREME - Regional Library of Medicine.

The following inclusion criteria were used: articles published in Portuguese, English and Spanish. As exclusion criterion: review articles that did not directly address the issue of irregular antibodies and blood transfusion.

The descriptors used were blood transfusion, antibodies to the $\mathrm{Rh}$ and Kell system, autoimmune hemolytic diseases, sickle cell anemia, thalassemias, sensitization by anti-D antibodies, immunoglobulin D and hemolytic anemia. From these descriptors the articles were selected covering blood transfusions and the results of the identification of irregular antibodies in patients who underwent blood transfusion.

\section{Results and discussion}

There were 51 articles in alternate sites: 43 in Scielo, 2 BIREME, 1 LILLACS and 5 in PubMed. Only 22 articles met the inclusion criteria proposed for the 
study. From this total of articles selected, they were distributed in several categories of descriptive, qualitative or quantitative studies. Of these articles analyzed for study, they were published in the period from 2000 to 2014.

VIEIRA et al. (2009) reported that blood group genotyping is successfully performed in transfusion therapies. The molecular techniques PCR and PCRRFLP is used successfully in large blood banks in the results in that the serological techniques are ineffective for conclusion of the results. The extended use of these techniques in patients entering a blood transfusion program greatly reduces erythrocyte sensitization.

Additionally, PERON et al. (2013) concluded that polytransferred patients are more sensitized due to the amount of transfused red blood cells. The use of phenotyped red cells for the antigens of the Rh, Kell, Duffy, Kidd and MNSs system is fundamental. Although patients who already exhibit irregular antibodies may be more likely to acquire new erythrocyte antibodies.

STINGHEN et al. (2013) found that phenotypes should be performed on all blood transfusions even if antibodies were not identified in alloimmunized patients. Di antibody was shown to be relevant and meaningful in their studies because it can be the cause of transfusion hemolytic diseases in neonatal. He also confirmed in his conclusions that the greater the number of blood transfusions performed, the patients are exposed to unusual antibodies, leading to the development of erythrocyte antibodies.

In a complementary manner, SOUZA et al. (2012) reported that pretransfusion phenotypes should be widely used in transfused red blood cells in patients in clinical, surgical and acute disease states. And these therapeutic transfusions must be phenotyped with $\mathrm{HC}$ compatible with the $\mathrm{Rh}$ and Kell system.

RUAS et al. (2013) observed that in the majority of transfused patients where phenotyping was performed there was a decrease in alomimunization.

PINHEIROS and collaborators (2013) reported the importance of blood group knowledge and blood donation.

MEDEIROS et al. (2010) reported that in blood donors from the Hemotherapy Service of the municipality of Primavera do Leste, several different phenotypes were found between blood groups $\mathrm{O}, \mathrm{A}, \mathrm{B}$ and $\mathrm{AB}$. They found that the most frequent phenotype was of the $\mathrm{O}$ group and the less frequent $\mathrm{AB}$. $\mathrm{He}$ also noted the predominance of class $\mathrm{O}, \mathrm{Rh}+$ and $\mathrm{A}, \mathrm{Rh}+$, but the lowest prevalence was the class AB, Rh-.

NARDOZZA et al. (2009) concluded that all Rh negative pregnant women should determine the blood group. They should be informed of the possibility of blood incompatibility related to their partners. If they are positive or unknown, the pregnant woman will perform an indirect coombs if she remains negative, it is recommended that intra-D anti-D prophylaxis be performed at the 28 th week and the first 72 hours after delivery or up to 28 days being reapplied every 12 weeks in pregnant women. Although atypical gestational events such as molar or ectopic gestation, genital bleeding and abdominal trauma in pregnancy, chorionic villus sampling, amniocentesis, funiculocenesis, external cephalic version or fetal death, intramuscular anti-D is recommended for the first 72 hours After the event. Attenuated virus vaccines should only be applied six months after anti-D administration. 
COSTA et al. (2000) observed that the identification of the Rh, Kell, Duffy and Kidd phenotypes in conjunction with the A, B, O system prevents erythrocyte sensitization and distinguishes antibodies in patients with $B$ thalassemia. Although it is costly, the RFLP PCR method is used in detriment of the phenotyping of these patients.

CASTILHO et al. (2006) reported that poor RhD antigen is not always identified in serological and immunohematological methods. In this case molecular techniques are used to distinguish weak RhD types. The identification of weak RhD is performed by the direct human anti-globulin test at room temperature with anti-D IgM and the anti-D human IgG antiglobulin test. However, in this study the anti-D IgM test revealed no partial Dfraco antigens and no density-decreasing antigens used in the routine of the patients. Thus, antiD IgG was shown to be effective in identifying total Dfraco in partial Dfraco aggregations, making it a routine blood donor test.

SILVA et al. (2011) reported the importance of phenotyping for Rh and Kell system antigens due to the immunogenicity of these antibodies causing associations with other types of antibodies. Rh negative with donors should be analyzed when presenting antigens $\mathrm{E}, \mathrm{C}$ or $\mathrm{K}$ following the protocols of the legislation. This idea is reinforced because antibodies can cause significant DHPN and sensitize other phenotypes.

KURODA et al (1998) concluded that the direct manual test Polybreneß (TPD) has high action on the TCD. The TPD method is fast and inexpensive, making it a helper method in the diagnosis of autoimmune hemolytic anemia (AIHA).

NETO et al (2013) reported that the antiglobulin test is effective in the diagnosis of autoimmune anemia which may be caused by changes in hemoglobin in red cell structure or drug-induced anemias.

PLECTSH and colleagues (2013) found that human direct antiglobulin test was applied to blood donors in direct Coombs test method. When he identified the positive hemolytic disease; the application of the test was performed in all the packed red blood cells to be transfused, establishing a protocol, thus avoiding future problems related to the positive TAD.

MORON et al. (2010) pointed out that the molecular elucidation of the Rh system determines the variants related to this system population. Molecular biology is being used to identify Rh negative phenotypes in pregnant patients with enlargement of the genotypes and the prevention of Rh alloimmunization. The primacy of the molecular method avoids the anti-D immunoprophylaxis in $\mathrm{RhD}$ negative pregnant women and the variations found in the $\mathrm{RhD}$ type Dfraco full and partial Dfraco.

SANTOS et al. (2011) conclude that the superiority of alloimmunization in patients with sickle cell disease (SS) was relevant because of the identified antibodies are systems of blood groups Rh and Kell. Thus, the importance of extending erythrocyte phenotyping blood donors and patients to prevent the reduction of alloimmunization risk.

HIRTSCH and colleagues (2004) reported the importance of including the identification of antigen $\mathrm{Di}^{\mathrm{a}}$ (Diego) in research (RIA) in any population, because this antibody and very significant and cause awareness in pregnant women at delivery. 
MIYADALINA 2000, found that still remains a serious problem alloimmunization related to $\mathrm{Rh}$. This is due to failures in the use of prophylaxis of $\mathrm{Rh}$ alloimmunization in prenatal and postpartum; that prophylaxis should be applied as prevention erythrocyte sensitization in Rh negative women.

Chamone and colleagues (2003) proposed the investigation of anti-U antibody when it is found in black and brown women the identification of high affinity antibodies.

MORITZ et al. (2009) reported the characterization of granulocyte antigens. The molecular basis can be identified through the use of genotyping PCRSSP (single primer specific - polymerase chain reaction). However, due to shortage of reagents and testing kits of commercial antibodies neutrophils are few conducted restricting the specialized laboratories in granulocyte immunology; so not all cases of neutropenia immune are investigated. Due to advances in diagnostic technology it is believed that this will facilitate the prevention of future transfusion reactions and autoimmune diseases caused by neutrophils.

DUARTE et al (2008) envisioned the technology of erythrocytes magnetized EM(R) Technology, a major innovation in imunohematológicos trials. The manual equipment used in Freelys(R)Nano name Workstation is an easy-handling equipment, economic and utilizes a small sample volume. In this equipment is made blood ratings $\mathrm{ABO}, \mathrm{RhD}, \mathrm{PC}$, fenotipagens and $\mathrm{RIA}$. In this method occur $100 \%$ of methodological efficacy in pre-transfusion testing. However, the RIA and PC was made using an IgG antiglobulin 37 which allowed the identification of IgG antibodies in phase. The brazilian RDC n 153 of June 14, 2004 determines the detection of antibodies in 37 significant at the stage of HAG, but the equipment of EM(R)Techonology does not identify IgM antibodies.

JUNIOR et al. (2004) reported that the application of molecular techniques PCR in conjunction with the hemagglutination in transfusion medicine, increases the safety of blood transfusions. About this genotyping technique not know if you can come and replace the hemagglutination future, but together has great potential value in transfusion and maternal and fetal safety.

In the period 2012-2013 the $\mathrm{Rh}$ and Kell system antibodies are the most common in our results, these antibodies are acquired through incompatible transfusions $\mathrm{HC}$ without erythrocyte fenotipagens, causing the sensitization on the patient. This is due to antibody inducibility the immune response of the recipient.

We observed significant incidence of major anti-E, anti-C, anti-K, anti-D, anti-Fy a, anti-Jk a and minor anti-F, anti-C, anti-S and anti- s.

The presence of anti-D, can be a blood donor with Rh D antigen presenting a partial, not identified in the use of monoclonal anti-D antisera, allowing the production of anti-D.

Patients who undergo blood transfusion due to decreased survival of red blood cells caused by the disease, leaving the patient vulnerable to develop erythrocytic alloantibodies. Thus the use of phenotyped red blood cells to the antigens of the Rh system, Kell, Duffy, Kidd and MNSs are essential to prevent the formation of new alloantibodies in alloimmunized patients. For these individuals already alloimmunized are more likely to produce irregular antibodies compared to individuals not sensitized.

We note that the identification of irregular antibodies is more relevant in patients receiving blood transfusion. As irregular antibodies are in most clinical 
significance increasing interest in research of irregular antibodies in future transfusions in patients with acute and chronic diseases, in cases of emergency care or in diseases such as hemolytic anemia and non-hemolytic.

The main antibodies were agrupadamente independent of the patient's illness related to the number of blood transfusions performed, emergency and urgent, number of pregnancy and the occurrence of different gestational partners. Because not be performed phenotyping before blood transfusions occurs future consequences to the welfare of the patient in transfusion therapy.

In this study we noted that the identified primary antibodies were anti-K, anti-E, anti-c, anti-D, anti-Fy a, anti-F, anti-C, anti-S, anti-Dihydroxy. In anti-D case was reported identification of this antibody in patients who had no history transfusion because of a treated primary sensitization.

Analyzing the results and discussion, we observe methods used currently applied in the pre-transfusion research to prevent immediate or future transfusion reactions. Some authors cite the importance of phenotyping and genotyping prior blood transfusions, but not all hemotherapy units perform these tests without a prescription and because of the unwillingness of the test equipment and performed manually. Molecular biology has proved to be a breakthrough in the pre-transfusion research in the identification of antibodies to Rh systems, kel, Duffy, Kidd and MNSs, preventing future sensitization, but not all hemotherapy units can make use of the methods in PCR, due to high cost of the apparatus. Then apply the methods and gel tubes but is not as effective in solving the false positive results.

Thus, the Brazilian Ministry of Health in conjunction with the RDC $\mathrm{n}^{\circ} 153$ reinforce the use of blood fenotipagens with negative red blood cell for individuals who have the positive antibodies.

\section{Conclusion}

This study demonstrated a significant frequency of irregular antibodies identified in patients who undergo blood transfusion. Most of these antibodies is of significance are the Rh, Kell, Duffy and Kidd and clinical insignificance are the MNSs system. The most common antibodies are Rh and Kell system.

It was observed that the identified antibodies in pre-transfusion research occur greatly due to the awareness of patients linked to the number of transfusions and the association between the $\mathrm{Rh}$ antibodies and Kell may disappear after months remain in the body.

Antibodies identified in association with other antibodies were anti-K, anti-E, anti-D, anti-C, anti-Fy a, anti-F, anti-C, anti-C, anti-S and anti-Dihydroxy. These antibodies goes unnoticed in research in pre-transfusion blood transfusion, causing immune hemolytic diseases or immediate / delayed or until the patient morbidity reactions.

We conclude that the antibodies identified in transfused patients are relevant and worrying. Thus, applies the need for infusion concentrates phenotyped erythrocytes for the $\mathrm{Rh}$ antigens, Kell, Duffy, Kidd, MNSs and others, and carrying out the genotyping of blood groups for hemotherapeutic treatment with safety and quality for the patient. 


\section{References}

ANDRADE ${ }^{\mathrm{a}}$, M.V.M, et al. Transfusão de Hemocomponentes na Urgência - Blood Transfusion in Emergency. Rev. Med. MINAS GERAIS 2010; 20(2 supl 1): S82-S86.

ANDRADE ${ }^{b}$, M.V.M et al. Mapeamento do Sistema de Grupos Sanguíneos ABO em Rondonópolis MT. Revista Biodversidade - pag.51, 2014.

BORDIN, O.J;. Aloimunização após transfusão de concentrado de hemácias em pacientes atendidos em um serviço de emergência. Rev. Bras. Hematol. Hemoter. 2007; 29(4):339-343.

BRITO, G. M.A, et. al. Contribuição ao Estudo da Prática Transfusional e suas Implicações Imunohematológicas. Revista NewsLab - edição 126, ano 2014.

BRASIL. Ministério da Saúde Agencia Nacional de Vigilância Sanitária. Resolução RDC n⿳0 153 , de 14 de junho de 2004. Disponível em:

$<$ portal.anvisa.gov.br/wps/wcm/connect/4bc8428047457945865fd63fbc4c6735/rdc_153.pdfw?M $\mathrm{OD}=\mathrm{AJPERES}>$. Acesso em: $27 \mathrm{de}$ fev.2015.

BRASIL. Ministério da Saúde Agencia Nacional de Vigilância Sanitária. Resolução RDC no 153 , de 14 de junho de 2004. Disponível em:

$<$ portal.anvisa.gov.br/wps/wcm/connect/4bc8428047457945865fd63fbc4c6735/rdc_153.pdfw?M $\mathrm{OD}=\mathrm{AJPERES}>$. Acesso em: 27 de fev.2015.

CASTILHO $^{\text {a }}$, l. O futuro da aloimunização eritrocitária. Rev. Bras. Hematol. Hemoter. 2008;30(4).

COVAS, D.T, et al. Hemoterapia: Fundamentos e prática. São Paulo: Editora Atheneu, p. 143, 2007.

CASTILHO $^{\text {b }}$, I., et. al. Avaliação de Reagentes anti-D na Detecção dos Antígenos D fraco e D parcial/ Evaluation of anti-D reagentes in the detection of weak D and parcial D antigens. Rev. Bras. Hematol. Hemoter.; 28 (4): 269 - 274, 2006.

COSTA, F. F. et al. Genotyping of Kell, Duffy, Kidd and RHD in patients With beta Thalassemia/ Genotipagem dos sistemas Kell, Duffy, Kidd e RHD em Pacientes com beta Talassemia. Rev. Bras. Hematol. Hemoter. 2000; 22 (2): 69-76, ILUS, TAB.

CHAMONE, F. A. D., et al. Hemolytic discase of the newborn due to anti-U / Doença Hemolitica do recem nascido devido a anti-U. Rev. Hosp. Clin. Vol. 58 nํㅜㅇ, São Paulo 2003.

DUARTE, L.E.M, et al. Desempenho da Tecnologia dos Eritrocitos magentizados (E.Mß) Tecnology) nos Testes Imunohematológicos. Ver Bras. Hematol. Hemoter. 2008; 30 (5): 374-378.

HIRTSCH, V. M. I., et al. Anti-Diego (a) alloantibody in pregnant / Aloanticorpo anti-Diego (a) em gestante. Rev. Bras. Hematol. Hemoter. Vol. 26, n⿳⺈ 4, São José do Rio Preto Out/dez 2004.

HARMENING, Denize. Técnicas Modernas em banco de sangue e tranfusão - $4^{\mathrm{O}}$ Edição - São Paulo: Editora Revinter, p.178-179; p.; p.151-153;2006.

JUNIOR, P. J., et al. Blood group genotyping - Genitipagem de Grupos Sanguíneos. Revista Brasileira de Hematologia e Hemoterapia, 2004; 26 (2): 135-140.

KURODA, A.; et al. Diagnóstico laboratorial da anemia hemolítica auto-imune: características do teste manual direto do Polybrene. Rev Ass. Med Brasil 1998; 44(1): 16-20.

MEDEIROS, O. M., et. al. Mapeamento dos Sistemas de Grupos Sanguíneos ABO e Rh dos Doadores de Sangue em Primavera do Leste - MT. Revista Biodiversidade v. 9, n.1, 2010.

MORON, F. A., et al. The molecular basis of RH system and its aplications in obstetrics and transfusion medicine / Bases moleculares do sistema RH e suas aplicações em obstetrícia e medicina. Rev. Assoc. Med. Bras. Vol. 56, nº 6 Sao Paulo 2010.

MIYADALINA, Seizo. Prevention of RH D Alloimmunization / Prevenção da Aloimunização RH American College of Obstetricians and Gynecologistes (ACOG) - Committee ar Practite Bulletins. Rev. Assoc. Med. Bras. Vol. 46 n 4, São Paulo Oct/Dec. 2000.

MORITZ E, et al. Human neutrophil alloantigens systems / Neutrófilo humano aloantigenos sistemas. An. Acad. Bras. Cienc. Vol. 81, nº 3, Rio de Janeiro, setembro 2009.

NARDOZZA, M. M. 1., E, et al. Aloimunização. Rev.Bras. Ginecol. Obstret. Vol 31 nº 6 Rio de Janeiro, 2009.

NOVARETTI, Z.C.M.,et al. Sistema de Grupo Sanguíneo Duffy: Biologia e Prática Transfusional/Duffy blood group system: Biology and transfusion pratice. Rev. Bras. Hematol. Hemoter. - 2005; 27 (2): 110-119.

NETO, P. R., et. al. Teste da Antiglobulina Humana na Rotina Labotatorial - Human Antiglobulin Teste in Laboratory Routine. Cadernos de Estudos e Pesquisas / vol. 17, no 38 (DEZ 2013) ISSN 2179-1562.

PINHEIROS, O. D. et al. Importância do Auto Conhecimento dos Grupos Sanguíneos (ABO e Rh) de Alunos de Tangará da Serra -MT.UNOPOAR Cient Cienc Biol Saúde, 199-202, 2013. 
PERON, F.D.L.M., et al. Aplicabilidade da Fenotipagem Eritrocitária em Doadores Voluntários e Pacientes Politransfundidos. Revista Saúde e Pesquisa, v. 6, n.3, p. 387-397, st./dez. 2013 ISSN $1983-1870$.

RUAS, M. K., et. al. Identificação de Anticorpos Irregulares no Hemocentro Regional de Montes Claros, MG - Identificacion de anticuerpos irregulares en el Hemocentro Regional de Montes Claros, MG - Identification of irregular antibodies Regional Blood Center in Montes Claros, MG. EFDeportes.com, Revista Digital. Buenos Aires. Año 17, nº 176, Enero de 2013.

STINGHEN, T.S., et al. Aloimunização Eritrocitária em Pacientes de um Hospital Infantil pelo Instituto Paranaense de Hemoterapia e Hematologia de 2007 a 2010 - Red cell alloimmunization in patients of a pediatric hospital serviced by the Instituto Paranaense de Hematologia e Hematologia, from 2007 to 2010.Cadernos da Escola de Saude, Curitiba, 6 131142 Vol. 2, ISSN 1984 - 7041, 2011.

SOUZA, M. V., et. al. Pesquisa de aloimunização após transfusão de concentrados de Hemácias em um estudo prospetivo - Hemocentro Regional de Uberaba - MG. Fundação Hemominas. Revista Brasileira Hematologia e Hemoterapia, 2012; 34(3): 206-11.

SANTOS, N.M.A.; et al. Fatores de Risco para Aloimunização em Pacientes com Anemia Falciforme. Rev. Assoc. Med. Bras 2011; 57 (6): 668-673.

SILVA P. E.J.; et al. Frequência do Sistema Rh e Kell nos Doadores do Hemocentro de Santa Maria - RS. Saúde (Santa Maria), v.37, n2, p-49-56, 2011.

VIEIRA, M.Z, et. al. Uso da Genotipagem de Grupos sanguíneos na Elucidação de Casos Inconclusivos na fenotipagem eritrocitária de Pacientes Atendidos na Fundação Hemominas Blood group genotyping to solve inconclive phenotyping cases of patients from the Hemominas Foundation. Revista Brasileira de Hematologia e Hemoterapia. 2009; 31(4): 242-259.

VAZ ${ }^{\text {a }}$ C.A.F,et al. Prevalência de Marcadores Imunohematológicos em Recém - Nascidos ao Nascimento e em suas Respectivas Mães e Incidência de Doença Hemolítica numa Maternidade de São Paulo. Rev. Assoc. Med. Bras. 49 (1): 45-53, 2003.

VAZ ${ }^{\mathrm{b}}$, C.A.F., et. al. Doença Hemolítica Neonatal: Antígenos e Anticorpos Envolvidos. Pediatria (São Paulo) 2001; 23(3): 251-7. 